\section{Obligatorisk klassiker}

John Stuart Mill

Om friheten

178 s. Oslo: Vidarforlaget, 2010. Pris NOK 349 ISBN 978-82-7990-048-1

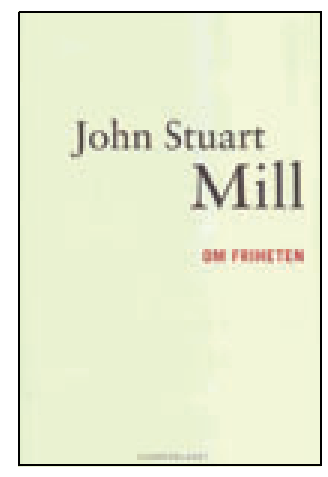

I 1859 utkom to bøker hvis innflytelse på vestlig tenkning om hva det vil si å være menneske, moralsk, politisk og religiøst, kanskje bare overgås av den kristne bibel. Den ene boken var Artenes opprinnelse (Origin of species) av

Charles Darwin (1809-82), den andre var Om friheten (On liberty) av John Stuart Mill (1806-73).

Bare av denne grunn er det storveies at Mills filosofiske klassiker nå er blitt gjort tilgjengelig i ny norsk språkdrakt. Første gang den utkom i Norge, var i 1947. Denne gangen er boken utstyrt med et informativt etterord av oversetteren Pål Foss. I bokens «introitus» avslører Mill to viktige inspirasjonskilder, den tyske dannelsesfilosofen Wilhelm von Humboldt (1767-1835), og sin avdøde kone, Harriet Mill (1807-58). En mer gripende takksigelse til en kjær og nær livsledsager og samarbeidspartner skal man lete lenge etter:

«Til det elskede og forgråtte minnet om henne som var inspiratoren og delvis forfatteren av alt som er av det beste i mine skrifter - en venn og hustru hvis opphøyde følelse for det som var sant og rett var mitt sterkeste insitament, og hvis bifall var min største belønning - tilegner jeg dette bindet. Akkurat som med alt jeg har skrevet over mange år. Er dette like mye hennes som min eiendom.»

Mills essay, som han kaller boken, er på knappe 130 sider og består av en innledning, et kapittel om tanke- og ytringsfrihet, et kapittel om individualiteten samt et kapittel om grensene for samfunnets makt over den enkelte. Til slutt følger et kapittel benevnt Anvendelser.

\section{Et friskt og åpent ordskifte}

Å gjenlese Om friheten er å bli påminnet om hvor skjør vår frihet er, hvor farlig det sosiale tyranniet kan være - selv i et demokratisk samfunn - og hvor viktig det er å tilstrebe meningsutveksling og uenighet. Mills begrunnelse for det siste, altså tankeog ytringsfriheten, er det verdt å gi en kortfattet fremstilling av denne: Fordi ingen av oss er guder, fordi selv de klokeste og mest kunnskapsrike blant oss ikke besitter hele sannheten, er det viktig for vår utvikling - både som enkeltmennesker og samfunn - at vi gir vår feilbarlighet rom i våre liv og våre ordninger. Av den grunn er det viktig å ta forholdsregler slik at tvilen i oss selv og andre - fritt og åpent får komme til uttrykk. I lett omskrevet form lyder disse fire forholdsreglene:

1. Selv meninger vi ønsker å bringe til taushet, kan inneholde et snev av sannhet. Derfor bør de få komme til orde.

2. Selv om den meningen vi bringer til taushet, viser seg å være feilaktig, kan den inneholde en del av sannheten, noe den ofte gjør.

3. Selv om den herskende mening ikke bare er sann, men også skulle romme hele sannheten, virker motstanden mot den rasjonelt skjerpende for de som deler den rådende oppfatningen.

4. Meningens kjerne og betydning vil bli svekket, berøves sin vitale virkning, og endog stå i fare for å gå tapt, om den ikke utsettes for kraftig og alvorlig motstand.

Dette oppsummerer hovedbudskapet i det store kapitlet om tanke- og ytringsfrihet. På tampen av gjennomgangen av dette kapitlet kan det være på sin plass å minne Tidsskriftets lesere om hva Mill her sier om ytringers form: «Før jeg forlater spørsmålet om meningsfrihet, passer det å se på dem som sier at alle meninger burde komme til uttrykk, men på betingelse av at det skjer på en avdempet måte, som ikke krenker normene for renhårig diskusjon. Mye kan sies om hvor umulig det er å fastsette slike grenser. Hvis prøvesteinen er at diskusjonsformen oppfattes som krenkende av dem hvis mening blir angrepet, så er dette et umulig kriterium.» (s. 64)

Hadde Rådet for legeetikk lagt disse visdomsordene til grunn for sin virksomhet, er det grunn til å tro at man, leger imellom, hadde fått et friskere og åpnere offentlig ordskifte enn tilfellet er i dagens Norge.

\section{Egen livsform er den beste}

Mens det første kapitlet handler om nødvendigheten av fri tanke- og meningsytring, er det enkeltmenneskers handlingsfrihet og grensene for denne friheten som undersøkes i det neste kapitlet: Individualiteten som en av forutsetningene for det allmenne beste. Den eneste legitime skranke i så måte, ifølge Mill, er at ens handlinger ikke går utover andre - $\mathrm{i}$ betydningen plager eller skader andre - eller hindrer andre fritt å leve ut sine handlinger etter egne overbevisninger. Av den grunn tar Mill også til orde for at samfunnet «på menneskehetens nåværende utviklingstrinn» bør legge forholdene til rette for at ulike livsformer og levemåter får mulighet til å komme til uttrykk: «Ethvert menneske med bare et minimum av sunn fornuft og erfaring har lov til å hevde at dets egen livsform er den beste. Ikke fordi det objektivt sett er det, men fordi det nå engang er den måten det har valgt å leve på.» (s. 80)

\section{Selvbestemmelse versus samfunnets makt}

I kapitlet Grensen for samfunnets makt over den enkelte drøfter Mill frihetsproblemet med utgangspunkt i fire spørsmål: Hvor går den riktige grensen for et menneskes rett til selvbestemmelse? Hvor begynner samfunnets makt? Hvilke deler av vårt liv kan vi bestemme over? Hvilke deler har samfunnet lov til å gripe inn i? Utgangspunktet for Mill er at enhver som nyter godt av samfunnets beskyttelse, står i gjeld til samfunnet som følge av denne fordelen. Utfordringen består dermed i å angi størrelsen på denne gjelden vis-à-vis samfunnet. Mills svar på disse spørsmålene er at i anliggender og forhold som bare angår individet selv, bør hver enkelt av oss ha frie tøyler. I det øyeblikk slik «tøylesløshet» gjør vedkommende ute av stand til å oppfylle sine forpliktelser overfor enkeltpersoner eller samfunnet, begår imidlertid vedkommende en sosial forbrytelse som det må sanksjoneres mot:

«Kort sagt: Hvor det foreligger en bestemt skade eller risiko - enten den nå går ut over enkeltpersoner eller samfunnet hører tilfellet ikke lenger inn under frihetens domene, men kommer inn under området for moral og lov.» (s. 97)

\section{Klok og velformulert}

I bokens siste kapittel, Anvendelser, formulerer Mill essayets to grunnprinsipper:

«1. Individet er ikke ansvarlig overfor samfunnet for sine handlinger så lenge disse ikke berører andre enn det selv.

2. Individet er ansvarlig for de handlinger som skader andres interesser, og for disse kan han ilegges sosial eller rettslig straff hvis samfunnet mener det er nødvendig av hensyn til dets sikkerhet.» (s. 111)

Mill var ikke bare en genial filosofisk og politisk tenker; han hadde også en sjelden evne til å formulere sine tanker i et språk som nådde ut til mange lesere. Boken burde være obligatorisk lesning for alle som har faglig myndighet til å intervenere i andre menneskers liv. I tillegg ville topp- og mellomlederne i våre helseforetak, direktorater og helsetilsyn utvilsomt hatt godt av å utsette seg for Mills visdom.

\section{Jan Helge Solbakk}

Senter for medisinsk etikk

Universitetet i Oslo 